\title{
APLIKASI PLANT GROWTH PROMOTING RHIZOBACTERIA (PGPR) TERHADAP PERTUMBUHAN BIBIT KAKAO (Theobroma cacao L.)
}

\author{
Julianus Jeksen \\ Julianus_jeksen@yahoo.com \\ Program Studi Agroekoteknologi, Fakultas Pertanian Universitas Flores, Ende
}

\begin{abstract}
This study aims at finding out the PGPR dose on the growth of cocoa seed and investigating the optimum dose of PGPR that can grow cocoa seed. A random block design was employed in this study with the treatment of 7,5 ml PGPR seed ${ }^{-1}$ (PG 1), and PGPR 15 ml PGPR seed ${ }^{-1}$ (PG 2), the PGPR dose of $30 \mathrm{ml} \mathrm{PGPR} \mathrm{seed}^{-1}$ (PG 3), and PGPR $45 \mathrm{ml}$ PGPR seed ${ }^{-1}$ (PG 4). The result of this research indicates that the treatment of PGPR dose has an apparent influence on the growth of cocoa seed. The better cocoa seed growth is that the plant height improves to $5,26 \%$, leaves total number of 5,64\%, leaves width of $8,36 \%$, diameter of stem increases to $12,00 \% \mathrm{~mm}$, the weight of wet fresh stover plant ${ }^{-1}$ rises $^{2}$ to $7,69 \%$ and dry weight of stover plant ${ }^{-1}$ increases to $10,71 \%$. The optimum dose of PGPR for cocoa seeding is $45 \mathrm{ml}$ PGPR seed ${ }^{-1}$.
\end{abstract}

Keywords: PGPR, Rhizobacteria, growth, cocoa seed, seeding

\section{Latar Belakang}

Tanaman kakao (Theobroma cacao

L.) merupakan salah satu komoditas andalan perkebunan yang peranannya cukup penting bagi perekonomian nasional Indonesia, khususnya sebagai penyedia lapangan kerja, dan sumber pendapatan. Selain itu, kakao juga berperan dalam mendorong pengembangan wilayah dan pengembangan agroindustri (ICCO. 2011).

Produksi kakao nasional mengalami penurunan yang cukup signifikan. Pada 2006 lalu, produksi kakao mencapai 590 ribu ton, lalu 2007 turun menjadi 520 ribu ton (Suriyani, 2008). Luas areal perkebunan kakao di NTT adalah 41.277,43 ha dan produksinya per tahun mencapai $29.857,4$ ton atau memiliki rata-rata produksi $723,33 \mathrm{~kg} / \mathrm{ha}$ (Dinas 
Julianus: Aplikasi plant growth promoting rhizobacteria (PGPR) terhadap pertumbuhan bibit kakao (Thebroma cacao L.)

Pertanian dan Perkebunan NTT, 2012). Berdasarkan data dari Dinas Pertanian Kabupaten Ende (2008) total luas lahan tanaman kakao adalah 5.532 ha yang mencapai total produksi 3.262 ton dengan produktivitas $589 \mathrm{~kg} / \mathrm{ha}$.

Menurunnya produktivitas kakao di Indonesia diakibatkan oleh banyaknya permasalahan yang terjadi dalam kegiatan budidaya mulai dari pembibitan, hama penyakit hingga panen. Salah satu permasalahan yang dihadapi mulai dari awal penanaman adalah teknologi pembibitan yang masih terbatas sehingga ketika ditanam dilapangan kualitas bibit sangat rendah bahkan tidak berkembang dengan baik (Susanto. 1994).

Untuk mencapai sasaran pengembangan dan produksi yang diharapkan perlu pengelolaan kebun yang baik, disamping pemeliharaan dan pemilihan bahan tanam yang sesuai. Salah satu penunjang untuk mencapai tujuan pelaksanaan produksi adalah dengan pembibitan yang baik dan benar. Peningkatan produksi kakao sejak awal dapat dilakukan dengan berbagai cara seperti pemakaian bibit yang baik, pemakaian pupuk yang tepat serta penggunaan ZPT. Pada pertumbuhan kakao, hal yang perlu diperhatikan adalah periode pertumbuhan bibit. Perlu adanya pelaksanaan pembibitan yang baik, karena pembibitan merupakan usaha permulaan kearah keberhasilan tanaman tersebut (Susanto. 1994).

Menurut Desmawati (2008) salah satu teknik budidaya yang dapat diterapkan adalah dengan menggunakan agen hayati (mikroba) yang bersifat menguntungkan bagi tanaman, termasuk sebagai agen penginduksi ketahanan, hidup di daerah sekitar perakaran (rizosfer), dimana terdapat eksudat yang dikeluarkan akar sebagai nutrisi bagi mikroba.

Sejak tahun 1970-an telah dilaporkan adanya kelompok mikroba yang secara khusus mengkoloni perakaran tanaman dan kemudian mulai diinokulasi sejak tahap awal penanaman (Kloeper. 1993). Dewasa ini kelompok mikroba tersebut dikenal dengan Plant Growth Promoting Rhizobacteria (PGPR), yaitu kelompok bakteri yang dapat mengkoloni perakaran tanaman dan memiliki kemampuan untuk merangsang pertumbuhan tanaman (Nelson 2004). Bakteri tersebut hidupnya secara berkoloni menyelimuti akar tanaman. Bagi tanaman keberadaan 
Julianus: Aplikasi plant growth promoting rhizobacteria (PGPR) terhadap pertumbuhan bibit kakao (Thebroma cacao L.)

mikroorganisme ini akan sangat menguntungkan.

Bakteri PGPR memiliki kemampuan sebagai penyedia hara disebabkan oleh kemampuannya dalam melarutkan mineral-mineral dalam bentuk senyawa kompleks menjadi bentuk ion sehingga dapat diserap oleh akar tanaman (Vessey. 2003). Kelompok bakteri PGPR ini yaitu Bacillus, Rhizobium Pseudomonas, azzototacter dan azospirrillum. (Anonim, 2012).

Pseudomonas sp dapat menghasilkan asam-asam organik seperti asam fomiat, asam asetat, dan asam laktat, propionat, glikolat, fumarat, oksalat, suksinat, tartrat, sitrat, laktat, dan ketoglutarat yang dapat melarutkan fosfat dalam bentuk yang sulit larut (Han \& Lee 2005). Asam-asam organik ini membentuk khelat dengan kation-kation pengikat $\mathrm{P}$ di dalam tanah seperti $\mathrm{Al}_{3}+$ dan $\mathrm{Fe}_{3}+$. Khelat tersebut dapat menurunkan reaktivitas ion-ion tersebut sehingga menyebabkan pelarutan fosfat yang efektif (Han \& Lee 2005); Pseudomonas sp. juga dapat melarutkan fosfat yang terikat dengan unsur lain menjadi tersedia bagi tanaman karena kemampuannya dalam menghasilkan enzim fosfatase dan fitase (Saraswati 2008).

Beberapa jenis bakteri PGPR (Plant Growth Promoting Rhizobacteria) yang berperan sebagai penambat $\mathrm{N}_{2}$ dari udara seperti Azotobacter dan Azospirillum yang jika berasosiasi dengan perakaran tanaman dapat membantu tanaman dalam memperoleh nitrogen melalui proses fiksasi nitrogen oleh mikroorganismemikroorganisme tersebut (Gardner dkk, 1991).

Aplikasi PGPR dapat dilakukan melalui pelapisan benih, perendaman benih dalam suspensi dan penambahan PGPR pada media tumbuh. Perlakuan PGPR merupakan alternatif yang cukup baik untuk digunakan dalam perlindungan tanaman karena PGPR dapat diaplikasikan ke benih atau dicampurkan ke dalam tanah untuk pembibitan atau saat pindah tanam (Taufik et al., 2005). Wirianti (2006) menyatakan bahwa pemberian perlakuan rhizobakteri selain berpengaruh terhadap tinggi tanaman cabai juga mampu memperbanyak jumlah daun.

Nassarudin (2011) melaporkan bahwa PGPR dengan konsentrasi $15 \mathrm{ml}$ PGPR/bibit ${ }^{-1}$ memiliki potensi lebih 
Julianus: Aplikasi plant growth promoting rhizobacteria (PGPR) terhadap pertumbuhan bibit kakao (Thebroma cacao L.)

mampu meningkatkan pertumbuhan bibit kakao yaitu rata-rata tinggi tanaman 47,9 cm; rata-rata jumlah daun 25,3 helai; ratarata luas daun 2013,06 $\mathrm{cm}^{2}$, rata-rata berat biomassa 17,08 gram, rata-rata berat segar akar 9,16 gram, rata-rata berat kering akar 3,84 gram dibandingkan dengan perlakuan kontrol yaitu rata-rata tinggi tanaman $34,0 \mathrm{~cm}$; rata-rata jumlah daun 17,8 helai; rata-rata luas daun $1260,5 \mathrm{~cm}^{2}$, rata-rata berat biomassa 10,13 gram, rata-rata berat segar akar 4,26 gram, rata-rata berat kering akar 2,02 gram. Berdasar uraian diatas, maka perlu dilakukan percobaan tentang Aplikasi Plant Growth Promoting Rhizobacteria (PGPR) Terhadap Pertumbuhan bibit tanaman Kakao (Theobroma Cacao L.).

\section{METODE PENELITIAN}

\section{Tempat dan Waktu Penelitian}

Percobaan ini dilaksanakan di Kelurahan Rewarangga Selatan, Kecamatan Ende Timur, Kabupaten Ende. Waktu percobaan dilaksanakan pada bulan Februari sampai Mei 2014.

\section{Bahan dan Alat Penelitian}

Bahan yang digunakan adalah bibit kakao, akar bambu, Air, air kelapa, Bekatul, Terasi. Alat yang digunakan adalah Jerigen, kompor, Corong, Panci, pengaduk, Saringan, Bak, Gayung, gunting pangkas, ember plastik, polybag, sendok, gelas ukur, gembor, mistar, alat tulis menulis, oven, alat timbang, kertas mm, pipet, papan LJK.

\section{Rancangan Percobaan}

Percobaan ini menggunakan rancangan acak kelompok (RAK) dengan perlakuan dosis PGPR yang terdiri dari 5 taraf yaitu :

PG $0=0 \mathrm{ml}$ PPR bibit ${ }^{-1}$ (kontrol)

PG 1=7,5 ml PGPR bibit ${ }^{-1}$

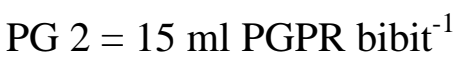

PG $3=30 \mathrm{ml}$ PGPR bibit ${ }^{-1}$

PG $4=45$ ml PGPR bibit ${ }^{-1}$

Masing-masing perlakuan diulang empat kali. Setiap perlakuan terdiri dari 6 tanaman, sehingga terdapat 120 polibag (tanaman) percobaan. Setiap perlakuan diambil 2 tanaman sampel.

\section{Variabel Penelitian}

Variabel yang diamati dalam penelitian ini adalah tinggi bibit $(\mathrm{cm})$, jumlah daun bibit ${ }^{1}$ (helai), luas daun bibit $\left(\mathrm{cm}^{2}\right)$, diameter batang $(\mathrm{mm})$, berat segar total tanaman ${ }^{-1}$, dan berat kering total $\operatorname{tanaman}^{-1}$. 
Julianus: Aplikasi plant growth promoting rhizobacteria (PGPR) terhadap pertumbuhan bibit kakao (Thebroma cacao L.)

\section{Analisis Data}

Data dianalisis menggunakan analisis sidik ragam sesuai dengan rancangan yang digunakan. Apabila perlakuan menunjukan pengaruh yang nyata pada variabel yang diamati, maka pengujian dilanjutkan dengan nilai rata-rata menggunakan uji BNT taraf 5\% (Gomez dan Gomez 1995).

\section{HASIL DAN PEMBAHASAN}

Hasil analisis statistik menunjukan bahwa perlakuan dosis PGPR berpengaruh sangat nyata terhadap variabel pertumbuhan tanaman kakao pada setiap umur pengamatan. Hasil analisis sidik ragam menunjukan bahwa peningkatan pemberian PGPR diikuti peningkatan pertumbuhan tanaman, ratarata total pertumbuhan pada tinggi tanaman dari PG0 ke PGI adalah 9,14\%, PGI ke PG2 3,77 \%, PG2 ke PG3 5,18 $\%$, PG3 ke PG4 5,26\%. Pada pertumbuhan jumlah daun dengan total rata-rata peningkatan dari PG0 ke PGI adalah 5,84\%, PGI ke PG2 4,48 \%, PG2 ke PG3 5,22 \%, PG3 ke PG4 5,64\%. Pada pertumbuhan luas daun dengan total ratarata peningkatan dari PG0 ke PGI adalah 9,43\%, PGI ke PG 5,94\%, PG2 ke PG3 7,62 \%, PG3 ke PG4 8,36\%. Pada pertumbuhan diameter batang dengan total rata-rata peningkatan dari PG0 ke PGI adalah 22,77\%, PGI ke PG2 12,95 $\%$, PG2 ke PG3 11,63 \%, PG3 ke PG4 $12,00 \%$.

Hal ini menunjukkan bahwa pemberian pada dosis $45 \mathrm{ml}$ PGPR bibit ${ }^{-1}$ lebih mampu meningkatkan pertumbuhan tanaman yaitu dapat meningkatkan pertumbuhan tinggi tanaman sebesar $5,26 \%$, meningkatkan jumlah daun sebesar 5,64\%, meningkatkan luas daun sebesar 8,36\%, dan meningkatkan diameter batang sebesar $12,00 \%$.

Peningkatan pertumbunhan tanaman akibat pemberian PGPR dikarenakan PGPR mampu menyediakan mikrobamikroba yang membantu mengurai bahan organik tanah menjadi unsur hara bagi tanaman seperti N, P, K. Bakteri-bakteri seperti Pseudomonas sp. dan Bacillus sp. dapat menghasilkan asam-asam organik seperti asam fomiat, asam asetat, dan asam laktat, propionat, glikolat, fumarat, oksalat, suksinat, tartrat, sitrat, laktat, dan ketoglutarat yang dapat melarutkan fosfat dalam bentuk yang sulit larut (Han \& Lee 2005). Asam-asam organik ini membentuk khelat dengan kation-kation pengikat $\mathrm{P}$ di dalam tanah seperti $\mathrm{Al}_{3}+$ 
Julianus: Aplikasi plant growth promoting rhizobacteria (PGPR) terhadap pertumbuhan bibit kakao (Thebroma cacao L.)

dan $\mathrm{Fe}_{3}+$ Khelat tersebut dapat menurunkan reaktivitas ion-ion tersebut sehingga menyebabkan pelarutan fosfat yang efektif (Han \& Lee 2005); Bacillus sp. dan Pseudomonas sp. juga dapat melarutkan fosfat yang terikat dengan unsur lain menjadi tersedia bagi tanaman karena kemampuannya dalam menghasilkan enzim fosfatase dan fitase (Saraswati 2008). Phospat yang tersedia bagi tanaman berfungsi untuk merangsang pertumbuhan akar terutama pada awal-awal pertumbuhan, pembelahan sel, mempercepat pembungaan dan pemasakan biji/buah.

Bakteri PGPR juga berperan sebagai penambat $\mathrm{N}_{2}$ dari udara untuk peningkatan penyediaan $\mathrm{N}$ tanah. Fiksasi $\mathrm{N}_{2}$ secara biologis mampu menyumbang kurang lebih $70 \%$ dari seluruh fiksasi $\mathrm{N}$ di muka bumi. Kurang lebih 50\% dari hasil fiksasi tersebut merupakan hasil asosiasi rhizobia-legum (Arshad, 1993). Beberapa jenis bakteri PGPR (Plant Growth Promoting Rhizobacteria) yang berperan sebagai penambat $\mathrm{N}_{2}$ dari udara seperti Azotobacter dan Azospirillum yang jika berasosiasi dengan perakaran tanaman dapat membantu tanaman dalam memperoleh nitrogen melalui proses fiksasi nitrogen oleh mikroorganismemikroorganisme tersebut (Gardner dkk, 1991).

Azotobacter adalah rhizobakteria yang telah dikenal sebagai agen biologis pemfiksasi nitrogen, yang mengubah nitrogen menjadi amonium melalui reduksi elektron dan protonasi gas nitrogen (Isminarni et. al. 2007). Nitrogen yang terikat pada struktur tubuh mikroba dilepas dalam bentuk organik sebagai sekresi atau setelah mikroba tersebut mati. Isminarni et. al. (2007) melaporkan bahwa jumlah Azotobacter berbanding lurus dengan jumlah $\mathrm{N}_{2}$ yang dapat diubah oleh sel Azotobacter. Unsur nitrogen ini digunakan oleh tanaman untuk pertumbuhan vegetatif seperti akar, batang dan daun.

Hal ini sejalan dengan penelitian vassey (2003) yang menyatakan bahwa Bakteri PGPR memiliki kemampuan sebagai penyedia hara disebabkan oleh kemampuannya dalam melarutkan mineral-mineral dalam bentuk senyawa kompleks menjadi bentuk ion sehingga dapat diserap oleh akar tanaman . Hamim et al. (2007) menyatakan bahwa terdapat korelasi yang baik antara aplikasi PGPR dengan peningkatan serapan hara makro 
Julianus: Aplikasi plant growth promoting rhizobacteria (PGPR) terhadap pertumbuhan bibit kakao (Thebroma cacao L.)

dan mikro pada tanaman sehingga memacu pertumbuhan dan produksi tanaman.

Hasil analisis data juga menunjukkan bahwa hipotesis $15 \mathrm{ml}$ PGPR bibit ${ }^{-1}$ (PG2) tidak terbukti memberikan hasil yang optimal terhadap pertumbuhan tinggi tanaman, jumlah daun, luas daun serta diameter batang bibit kakao. Peningkatan pertumbuhan yang optimal terjadi pada perlakuan PG4 dengan dosis $45 \mathrm{ml}$ PGPR bibit $^{-1}$ Hal ini dikarenakan PGPR mengandung bakteri-bakteri dengan peran positif dalam mendukung pertumbuhan tanaman. Bakteri-bakteri tersebut dapat positif dapat membuat $\mathrm{P}$ menjadi tersedia, mengikat $\mathrm{N}$ dari udara dan membuatnya tersedia bagi tanaman, menyediakan hormon tumbuh bagi tanaman (Anonim, 2011; Arshad, 1993). Jadi semakin tinggi dosis PGPR yang diberikan maka semakin baik pertumbuhan tanaman.

Hasil analisis sidik ragam untuk variabel berat basah berangkasan $\operatorname{tanaman}^{-1}$ dan berat kering berangkasan $\operatorname{tanaman}^{-1}$ menunjukkan bahwa peningkatan pemberian dosis PGPR berbanding lurus dengan peningkatan berat basah berangkasan tanaman ${ }^{-1}$ dan berat kering berangkasan tanaman ${ }^{-1}$.
Dengan total rata-rata peningkatan berat basah berangkasan tanaman ${ }^{-1}$ dari PG0 ke PGI adalah 23,47\%, PGI ke PG2 1,01 \% , PG2 ke PG3 8,33 \%, PG3 ke PG4 7,69\%. Dan total rata-rata peningkatan berat kering berangkasan $\operatorname{tanaman}^{-1}$ dari PG0 ke PGI adalah 35,56\%, PGI ke PG2 4,26\% , PG2 ke PG3 6,00\%, PG3 ke PG4 $10,71 \%$. Hal ini menunjukkan bahwa pemberian PGPR terbaik yaitu pada perlakuan PG4 (45 ml PGPR bibit ${ }^{-1}$ ) yaitu dengan meningkatkan berat segar brangkasan tanaman ${ }^{-1}$ sebesar 7,69 \% dan meningkatkan berat kering brangkasan tanaman $^{-1}$ sebesar $10,71 \%$.

Peningkatan berat segar basah brangkasan tanaman ${ }^{-1}$ dan berat kering brangkasan $\operatorname{tanaman}^{-1}$ berhubungan dengan kemampuan PGPR dalam meningkatkan pertumbuhan tanaman dengan mensintesis hormon tumbuh, memfiksasi nitrogen dan melarutkan fosfat (Matiru, 2004). Azotobacter selain dapat mengikat $\mathrm{N}_{2}$ dari udara, juga mampu menghasilkan Asam Indol Asetat (IAA) dalam jumlah yang berbanding lurus dengan kepadatannya. Selain itu, Azotobacter juga dapat menghasilkan sitokinin, giberelin, dan asam absisat (ABA) (Haefele et al. 2008). 
Julianus: Aplikasi plant growth promoting rhizobacteria (PGPR) terhadap pertumbuhan bibit kakao (Thebroma cacao L.)

Azospirillum dan Pseudomonas juga memiliki kemampuan dalam menghasilkan zat pengatur tumbuh. Azospirillum dapat menghasilkan IAA yang berguna untuk merangsang pertumbuhan akar, sedangkan Pseudomonas dapat menghasilkan sitokinin untuk pertumbuhan tajuk (Salamone et al. 2001). Nelson (2004) juga mengemukakan bahwa pemberian PGPR mampu mendorong pertumbuhan dan produksi yang disebabkan oleh akumulasi nutrien seperti $\mathrm{N}$ dan $\mathrm{P}$ dan senyawa lain yang diinduksi oleh mikroorganisme. Dengan peran yang penting tersebut, maka dosis yang semakin tinggi dari PGPR akan semakin mendukung pertumbuhan tanaman. Sehingga diasumsikan bahwa dosis optimum PGPR dalm meningkatkan pertumbuhan tanaman adalah $45 \mathrm{ml} /$ bibit $^{-}$ 1 .

\section{Kesimpulan}

1. Penambahan dosis PGPR berpengaruh sangat nyata meningkatkan rata-rata pertumbuhan tinggi tanaman sebesar 5,26 \%, jumlah daun sebesar 5,64\%, luas daun sebesar $8,36 \%$, diameter batang sebesar
$12,00 \% \mathrm{~mm}$, berat segar basah brangkasan tanaman ${ }^{-1}$ sebesar 7,69 $\%$ dan berat kering brangkasan $\operatorname{tanaman}^{-1}$ sebesar $10,71 \%$.

2. Dosis optimum PGPR untuk bibit kakao terbaik adalah $45 \mathrm{ml}$ PGPR bibit $^{-1}$ yaitu meningkatkan rata-rata pertumbuhan tinggi tanaman sebesar 41,13 cm, jumlah daun sebesar 14,38 helai, luas daun sebesar $426,76 \mathrm{~cm}^{2}$, diameter batang sebesar $13,71 \mathrm{~mm}$, berat segar basah brangkasan tanaman ${ }^{-1}$ sebesar 14,63 gram dan berat kering brangkasan tanaman ${ }^{-1}$ sebesar 7,00 gram.

\section{Ucapan Terima Kasih}

Pada kesempatan ini penulis ingin mengucapkan terima kasih kepada semua pihak yang telah membantu dengan caranya masing-masing dalam melengkapi tulisan ini.

\section{DAFTAR PUSTAKA}

Anonim. 2011. Cara Membuat PGPR, Bakteri Pemacu Pertumbuhan Tanaman. http://bpplentengsumenep.blogspot.c om/2011/05/cara-membuat-pgprbakteri-pemacu.html Diakses pada hari Senin tanggal 8 April 2013 pukul 23.35 WITA. 
Julianus: Aplikasi plant growth promoting rhizobacteria (PGPR) terhadap pertumbuhan bibit kakao (Thebroma cacao L.)

Anonim. 2012. Pembuatan dan Pengaplikasian PGPR pada tanaman. http://kuliahagroteknologi.blogspot.c om/2012/06/pembuatan-danpengaplikasian-pgpr-plant.htlm. Diakses pada hari Senin tanggal 8 April 2013 pukul 23.00 WITA.

Desmawati, 2008. Pemanfaatan Plant Growth Promoting Rhizobacter (PGPR) prospek yang menjanjikan dalam berusahatani tanaman hortikultura.

http://ditlin.hortikultura.go.id/tulisan/ desmawati.htm. Diakses tanggal 11 September 2012.

Direktorat Jendral Perkebunan. 2011. http: //ditjenbun. deptan.go.id / bbp2tpbon/index. php? Option = com_content\&view=article $\&$ id $=129$ : media-pembibitan-

kakao\&catid=12:news. ditjenbun @ deptan.go.id (10 Desember 2012 )

Ejar Irmawan. 2008. Bakteri Rhizosfer Pemacu Pertumbuhan (PGPR). http://www.pertaniansehat.or.id/inde x.php?pilih=news\&mod=yes\&aksi=1 ihat\&id=72 Diakses pada hari Selasa tanggal 9 April 2013 pukul 00.05 WITA

Gardner, F.P., R.B. Pearce, dan R.L. Mitchel. 1991. Fisiologi tanaman budidaya. Terjemahan. H. Susilo, Subiyanto (Ed). Jakarta:UI Press.

Gomez, K.A.,Gomez,A.A 2007. Prosedur statistic untuk penelitian pertanian. Edisi ke 2.Jakarta : Universitas Indonesia.

Hamim, Rachmania N, Hanarida I, Sumarni N. 2007. Pengaruh pupuk biologi terhadap pola serapan hara, ketahanan penyakit, produksi dan kualitas hasil beberapa tanaman pangan dan sayuran unggulan. Bogor. Lembaga Penelitian dan Pengabdian Masyarakat. IPB.

Isminarni $\mathrm{F}$, Wedhastri $\mathrm{S}$, Widada $\mathrm{J}$, Purwanto BH. 2007. Penambatan nitrogen dan penghasilan indol asam asetat oleh isolat-isolat Azotobacter pada $\mathrm{pH}$ rendah dan aluminium tinggi. J Ilmu Tanah dan Lingkungan. 7: 23-30

Mars Sustainibility. 2009. Peremajaan tanaman kakao dan praktek perkebunan yang baik. Mars Simbiosience Indonesia

Nassarudin. 2011. Respon Pertumbuhan Bibit Kakao Terhadap Dosis PGPR Dan Mikoriza. Skripsi. Fakultas Pertanian Universitas Hasanudin.

Nelson, L.M. 2004. Plant Growth Promoting Rhizobacteria (PGPR): Prospects for NewInoculants. http://www.plantmanagementnetwor k.org. Diakses tanggal 11 September 2012.

Rahmawati N. 2005. Pemanfaatan biofertilizer pada pertanian organik. USU Repository.

Ridwan. 2011. Pengaruh Pupuk Organik Dengan Pupuk Hayati Untuk Meningkatkan Efisiensi Hara, Pertumbuhan dan Produksi Tanaman Cabai. Thesis. Institute Pertanian Bogor. Bogor.

Saraswati R, Sumarno 2008. Pemanfaatan mikroba penyubur tanah sebagai 
Julianus: Aplikasi plant growth promoting rhizobacteria (PGPR) terhadap pertumbuhan bibit kakao (Thebroma cacao L.)

komponen teknologi pertanian. Iptek Tan Pangan 3(1): 49 - 50

Susanto, F.X. 1994. Tanaman Kakao Budidaya dan Pengolahan Hasil. Penerbit Kanisius : Yogyakarta.

Taufik, M., S.H. Hidayat, G. Suastika, S.M. Sumaraw dan S. Sujiprihati. 2005. Kajian Plant Growth Promoting Rhizobacteria (PGPR) sebagai agens proteksi Cucumber Mosaic Virus dan Chilli Veinal Mottle Virus pada Cabai. Hayati. 12 (4):139-144.

Tjitrosoepomo, 1988, Taksonomi Tumbuhan (Spermathopyta), Yogyakarta : Universitas Gadjah Mada.

Wirianti, D.A. 2006. Pengaruh Penggunaan Rhizobakteri Pemacu Pertumbuhan Tanaman terhadap Perkembangan Populasi Kutu Kebul Bemisia tabaci (Gennaduius) (Hemiptera:Aleyrodidae) pada Tanaman Cabai. Skripsi. Fakultas Pertanian. Institut Pertanian Bogor. Bogor. 44 hal.

Willy, Bryan. 2010. Standar Pembibitan. http://bryanwilly32.blogspot.com/20 10/07/standar-pembibitan.html diakses tanggal 20 Desember 2011 pukul 19.35 wib.

Wibowo ST. 2007. Respon morfologi dan fisiologi beberapa tanaman budidaya terhadap aplikasi kompos yang diperkaya dengan mikroba activator. [tesis]. Bogor: Program Pascasarjana, Institut Pertanian Bogor. 